\title{
Efficacy and Safety of the Selective Cyclooxygenase-2 Inhibitor Celecoxib in the Treatment of Rheumatoid Arthritis and Osteoarthritis in Japan
}

\author{
Choitsu Sakamoto $^{\text {a }}$ Satoshi Soen $^{b}$ \\ aDivision of Gastroenterology, Department of Internal Medicine, Nippon Medical School, Tokyo, and \\ ${ }^{b}$ Department of Orthopedic Surgery and Rheumatology, Nara Hospital, Kinki University School of Medicine, \\ Nara, Japan
}

\section{Key Words}

Celecoxib - COX-2 inhibitor, selective $\cdot$ Gastrointestinal

disorders $\cdot$ Cardiovascular disorders

\begin{abstract}
Background/Aims: Gastrointestinal (GI) disorders are common adverse reactions of nonsteroidal anti-inflammatory drugs (NSAIDs). Loxoprofen is a representative NSAID widely used in East Asia. A selective cyclooxygenase-2 inhibitor, celecoxib, was introduced in Japan in 2007. In this study, we aimed to compare the efficacy and safety of celecoxib with those of loxoprofen in Japanese patients. Methods: We analyzed the data from 12 clinical studies conducted in Japan. These data of Japanese patients were compared with those of the patients in the West that had been published after 2000. Results: The efficacy of celecoxib as an analgesic was comparable to that of loxoprofen, whereas serious Gl events, including symptomatic ulcers, were significantly less frequent with celecoxib than with loxoprofen in Japanese patients with rheumatoid arthritis (RA) and osteoarthritis (OA) $(p=0.039)$. These results were consistent with the findings of the studies conducted in the West. The incidence of serious cardiovascular events was $0.1 \%$ in 2,398 subjects on celecoxib, which was not statistically different from the inci-
\end{abstract}

dence in subjects on loxoprofen $(0.3 \% ; p=0.3404)$ and those on placebo $(0.2 \%)$; this result was also consistent with the data of the studies conducted in the West. Conclusion: The analgesic activity of celecoxib, which was used for the treatment of RA, OA, and low back pain, was comparable to that of loxoprofen, and celecoxib was safer in terms of Gl injury often caused by other nonselective NSAIDs.

Copyright $\odot 2010$ S. Karger AG, Basel

\section{Introduction}

Nonsteroidal anti-inflammatory drugs (NSAIDs) exert anti-inflammatory and analgesic effects by inhibiting cyclooxygenase (COX) activity in the arachidonic acid cascade, and thus inhibit prostaglandin (PG) synthesis [1]. In the 1990s, 2 COX isoenzymes - COX-1 and COX2 - were identified $[2,3]$. It is now well known that COX1 is expressed constitutively in a variety of tissues and is involved in PG synthesis under normal physiological conditions in which PG protects the gastric mucosa and maintains renal and platelet functions $[4,5]$. In contrast, COX-2 has been shown to be induced in inflamed tissues and is involved in PG synthesis associated with inflammation [6,7]. Thus, conventional NSAIDs that inhibit

\section{KARGER}

Fax +41613061234 E-Mail karger@karger.ch www.karger.com
(C) 2010 S. Karger AG, Basel

0012-2823/11/0832-0108\$38.00/0

Accessible online at:

www.karger.com/dig
Choitsu Sakamoto, MD, PhD

Division of Gastroenterology, Department of Internal Medicine

Nippon Medical School, 1-1-5 Sendagi, Bunkyoku

Tokyo 113-8603 (Japan)

Tel. +81 35802 8145, Fax +81 35802 8149, E-Mail choitsu@nms.ac.jp 
both COX-1 and COX-2 to varying degrees exert therapeutic effects by inhibiting COX-2. The adverse effects of NSAIDs, particularly in the upper gastrointestinal (GI) tract, are considered to be mainly caused by the inhibition of COX-1 activity, which is involved in gastric mucosal protection $[8,9]$. GI injury associated with NSAIDs is a serious clinical problem since NSAID-related ulcer complications have been estimated to lead to 10,000 cases of hospitalization and 16,500 deaths yearly in the United States [10]. Therefore, attempts were made to develop drugs targeted against COX-2 to reduce adverse reactions to NSAIDs, while retaining their anti-inflammatory and analgesic actions. In 1998, celecoxib was approved as the first selective COX-2 inhibitor [11]. Celecoxib is a member of the coxib family, which is a drug family included in the anatomical therapeutic chemical (ATC) classification system; it is characterized by a 3-dimensional structure of molecules designed to afford COX-2 selectivity [11]. Celecoxib has been available in Japan since June 2007 and is indicated for rheumatoid arthritis (RA), osteoarthritis $(\mathrm{OA})$, and inflammation and pain associated with $\mathrm{RA}$ or OA.

Despite cases of serious NSAID-related ulcer complications in the United States [10], few studies have reported NSAID-related upper GI injuries in Japan where the main cause of gastroduodenal ulcers is Helicobacter $p y$ lori; the prevalence of infection with $H$. pylori in Japan is much higher than in the United States [12]. In addition, the types and doses of NSAIDs used for the treatment of patients with RA or OA in Japan are very different from those used in the United States. For example, the maximum prescribed dose of diclofenac in Japan is $100 \mathrm{mg} /$ day, whereas in the United States it is $200 \mathrm{mg}$ /day. Furthermore, the most frequently prescribed NSAID in Japan is loxoprofen, which is a prodrug that is marketed only in Asia, Mexico, and Brazil, but not in the United States. The lower number of studies on the adverse effects of NSAIDs on gastroduodenal mucosa in Japan can be attributed to differences with regard to upper GI injury and its treatment in Japan and the United States. Therefore, it seems important for us to make it clear how the NSAIDs we usually use are safe or harmful in terms of drug-related gastroduodenal injury.

The aim of this study was to review the clinical efficacy and safety data of celecoxib in comparison with those of loxoprofen, which is a widely used form of propionic acid in East Asia, in Japanese trials and to inform doctors about the efficacy and safety of NSAIDs in Japanese patients with RA or OA.

Celecoxib in the Treatment of $\mathrm{RA}$ and $\mathrm{OA}$

\section{Clinical Efficacy of Celecoxib}

\section{Clinical Efficacy in RA Treatment}

Twelve phase II and III clinical trials of celecoxib, including 2 placebo-controlled double-blind trials, 2 double-blind loxoprofen-controlled celecoxib trials, and 1 double-blind placebo- and loxoprofen-controlled celecoxib trial, were conducted in Japan to evaluate the efficacy and safety of celecoxib in the treatment of patients with RA, OA, and low back pain (table 1). In these trials, a total of 2,410 patients received celecoxib, 1,190 patients loxoprofen, and 414 patients placebo [13-22]. The details of the trials are summarized in table 1 . The efficacy and safety of celecoxib in the treatment of patients with RA were examined in 4 trials, including a double-blind trial including 771 patients with RA to compare the efficacy and safety of 12 weeks' treatment with celecoxib $(200 \mathrm{mg}$ b.i.d.) with those of loxoprofen (60 mg t.i.d.) (table 1) [14]. In this trial, celecoxib was comparable to loxoprofen sodium in the evaluation of both final 'improvement rate' as a primary endpoint and 'time course of percent improvement' according to the American College of Rheumatology (ACR) Improvement Criteria (fig. 1). In 'selfassessment of pain by patients' using the visual analog scale (VAS), the scores revealed that the levels of improvement in patients in the celecoxib treatment group at 2 and 4 weeks after the start of treatment were significantly higher than the corresponding levels in patients in the loxoprofen sodium treatment group, thereby indicating that more rapid improvement can be achieved with celecoxib (fig. 2). These data are consistent with those of a previously published overseas study in which the efficacy of celecoxib (200 mg b.i.d.) in the treatment of patients with RA was compared to that of diclofenac SR (75 mg b.i.d.) [23].

These results showed that the efficacy of celecoxib in the treatment of patients with RA is comparable to that of conventional RA drugs such as loxoprofen sodium and diclofenac.

\section{Clinical Efficacy in OA Treatment}

The efficacy and safety of celecoxib in the treatment of patients with OA were also examined in 4 trials, including a double-blind trial, in 949 patients with OA to compare the efficacy and safety of 4 weeks' treatment with celecoxib (100 mg b.i.d.) with those of loxoprofen (60 mg t.i.d.) or placebo (table 1) [17]. In this double-blind trial, with regard to the rate of improvement in the final global improvement assessment (the primary endpoint), the level of improvement in the patients in the celecoxib group 
Table 1. List of 12 clinical trials conducted in Japan to evaluate the efficacy and safety of celecoxib in patients with RA, OA, and low back pain

\begin{tabular}{|c|c|c|c|c|c|c|c|c|}
\hline $\begin{array}{l}\text { Authors/ } \\
\text { year of } \\
\text { publication }\end{array}$ & $\begin{array}{l}\text { Disease } \\
\text { entity }\end{array}$ & Study design & $\begin{array}{l}\text { Pa- } \\
\text { tients } \\
\mathrm{n}\end{array}$ & $\begin{array}{l}\text { Facili- } \\
\text { ties } \\
\mathrm{n}\end{array}$ & Drug dose & $\begin{array}{l}\text { Patients who } \\
\text { received/completed/ } \\
\text { discontinued therapy } \\
\mathrm{n}\end{array}$ & $\begin{array}{l}\text { Term } \\
\text { weeks }\end{array}$ & Outcome and method of evaluation \\
\hline $\begin{array}{l}\text { Abe et al. } \\
{[13] / 2006}\end{array}$ & RA & Open & 54 & 18 & $\begin{array}{l}\text { Celecoxib } 50 \mathrm{mg} \text { b.i.d. } \\
\text { Celecoxib } 100 \mathrm{mg} \text { b.i.d. } \\
\text { Celecoxib } 200 \mathrm{mg} \text { b.i.d. }\end{array}$ & $\begin{array}{l}19 / 11 / 8 \\
17 / 14 / 3 \\
18 / 11 / 7\end{array}$ & 6 & $\begin{array}{l}\text { Determination of the rate of improve- } \\
\text { ment/self-assessment using VAS or } \\
\text { on the basis of adverse effects }\end{array}$ \\
\hline $\begin{array}{l}\text { Abe et al. } \\
{[13] / 2006}\end{array}$ & RA & $\begin{array}{l}\text { Randomized } \\
\text { double-blind } \\
\text { placebo-controlled }\end{array}$ & 423 & 112 & $\begin{array}{l}\text { Celecoxib } 25 \text { mg b.i.d. } \\
\text { Celecoxib } 100 \text { mg b.i.d. } \\
\text { Celecoxib } 200 \text { mg b.i.d. } \\
\text { Placebo b.i.d. }\end{array}$ & $\begin{array}{l}98 / 83 / 15 \\
89 / 83 / 6 \\
92 / 83 / 9 \\
95 / 75 / 20\end{array}$ & 4 & $\begin{array}{l}\text { Determination of the rate of improve- } \\
\text { ment on the basis of ACR improve- } \\
\text { ment criteria/self-assessment using } \\
\text { VAS or on the basis of adverse effects }\end{array}$ \\
\hline $\begin{array}{l}\text { Abe et al. } \\
{[14] / 2006}\end{array}$ & RA & $\begin{array}{l}\text { Randomized } \\
\text { double-blind } \\
\text { comparison of } \\
\text { celecoxib with } \\
\text { loxoprofen }\end{array}$ & 831 & 195 & $\begin{array}{l}\text { Celecoxib } 200 \mathrm{mg} \text { b.i.d. } \\
\text { Loxoprofen } 60 \mathrm{mg} \text { t.i.d. }\end{array}$ & $\begin{array}{l}382 / 319 / 63 \\
389 / 326 / 63\end{array}$ & 12 & $\begin{array}{l}\text { Determination of the rate of improve- } \\
\text { ment on the basis of ACR improve- } \\
\text { ment criteria/self-assessment using } \\
\text { VAS or on the basis of adverse effects, } \\
\text { including GI events }\end{array}$ \\
\hline $\begin{array}{l}\text { Azuma } \\
{[15] / 2006}\end{array}$ & RA & Open & 156 & 13 & $\begin{array}{l}\text { Celecoxib } \\
200-400 \mathrm{mg} \text { b.i.d. }\end{array}$ & $\begin{array}{l}200 \text { mg: } 111 / 78 / 33 \\
400 \text { mg: } 45 / 35 / 10\end{array}$ & 52 & $\begin{array}{l}\text { Determination of the rate of improve- } \\
\text { ment on the basis of ACR improve- } \\
\text { ment criteria/self-assessment using } \\
\text { VAS or on the basis of adverse effects }\end{array}$ \\
\hline $\begin{array}{l}\text { Aoki et al. } \\
{[16] / 2006}\end{array}$ & $\mathrm{OA}$ & Open & 65 & 22 & $\begin{array}{l}\text { Celecoxib } 25 \text { mg b.i.d. } \\
\text { Celecoxib } 50 \text { mg b.i.d. } \\
\text { Celecoxib } 100 \text { mg b.i.d. }\end{array}$ & $\begin{array}{l}20 / 16 / 4 \\
23 / 17 / 6 \\
18 / 15 / 3\end{array}$ & 4 & $\begin{array}{l}\text { Determination of the rate of } \\
\text { improvement/adverse effects }\end{array}$ \\
\hline $\begin{array}{l}\text { Aoki et al. } \\
{[16] / 2006}\end{array}$ & $\mathrm{OA}$ & $\begin{array}{l}\text { Randomized } \\
\text { double-blind } \\
\text { placebo-controlled }\end{array}$ & 518 & 89 & $\begin{array}{l}\text { Celecoxib } 25 \text { mg b.i.d. } \\
\text { Celecoxib } 50 \text { mg b.i.d. } \\
\text { Celecoxib } 100 \text { mg b.i.d. } \\
\text { Placebo b.i.d. }\end{array}$ & $\begin{array}{l}129 / 115 / 14 \\
125 / 108 / 17 \\
118 / 103 / 15 \\
127 / 110 / 17\end{array}$ & 4 & $\begin{array}{l}\text { Determination of the rate of } \\
\text { improvement/adverse effects }\end{array}$ \\
\hline $\begin{array}{l}\text { Sugawara } \\
{[17] / 2006}\end{array}$ & $\mathrm{OA}$ & $\begin{array}{l}\text { Randomized } \\
\text { double-blind place- } \\
\text { bo-controlled com- } \\
\text { parison of celecoxib } \\
\text { with loxoprofen }\end{array}$ & 959 & 85 & $\begin{array}{l}\text { Celecoxib } 100 \mathrm{mg} \text { b.i.d. } \\
\text { Loxoprofen } 60 \mathrm{mg} \text { t.i.d. } \\
\text { Placebo t.i.d. }\end{array}$ & $\begin{array}{l}377 / 342 / 35 \\
380 / 345 / 35 \\
192 / 177 / 15\end{array}$ & 4 & $\begin{array}{l}\text { Determination of the rate of improve- } \\
\text { ment/self-assessment using VAS/ } \\
\text { WOMAC OA index or on the basis } \\
\text { of adverse effects, including GI events }\end{array}$ \\
\hline $\begin{array}{l}\text { Sugawara } \\
{[18] / 2006}\end{array}$ & $\mathrm{OA}$ & Open & 65 & 4 & $\begin{array}{l}\text { Celecoxib } \\
100-200 \mathrm{mg} \text { b.i.d. }\end{array}$ & $\begin{array}{l}100 \mathrm{mg}: 55 / 40 / 15 \\
200 \mathrm{mg}: 10 / 8 / 2\end{array}$ & $28-52$ & $\begin{array}{l}\text { Self-assessment using VAS or on the } \\
\text { basis of adverse effects }\end{array}$ \\
\hline $\begin{array}{l}\text { Kikuchi } \\
\text { et al. } \\
{[19] / 2009}\end{array}$ & $\begin{array}{l}\text { Low } \\
\text { back } \\
\text { pain }\end{array}$ & $\begin{array}{l}\text { Randomized } \\
\text { double-blind } \\
\text { comparison of } \\
\text { celecoxib with } \\
\text { loxoprofen }\end{array}$ & 881 & 80 & $\begin{array}{l}\text { Celecoxib } 100 \mathrm{mg} \text { b.i.d. } \\
\text { Loxoprofen } 60 \mathrm{mg} \text { t.i.d. }\end{array}$ & $\begin{array}{l}425 / 400 / 25 \\
421 / 390 / 31\end{array}$ & 4 & $\begin{array}{l}\text { Improvement rate/self-assessment } \\
\text { using VAS or on the basis of adverse } \\
\text { effects, including GI events }\end{array}$ \\
\hline $\begin{array}{l}\text { Takagishi } \\
{[20] / 2009}\end{array}$ & $\begin{array}{l}\text { Periar- } \\
\text { thritis } \\
\text { of the } \\
\text { shoulder }\end{array}$ & Open & 81 & 13 & Celecoxib 100 mg b.i.d. & $77 / 70 / 7$ & 4 & $\begin{array}{l}\text { Improvement rate/self-assessment } \\
\text { using VAS or on the basis of adverse } \\
\text { effects }\end{array}$ \\
\hline $\begin{array}{l}\text { Takagishi } \\
{[21] / 2009}\end{array}$ & $\begin{array}{l}\text { Cervico- } \\
\text { omo- } \\
\text { brachial } \\
\text { syndrome }\end{array}$ & Open & 85 & 13 & Celecoxib 100 mg b.i.d. & $82 / 78 / 4$ & 4 & $\begin{array}{l}\text { Improvement rate/self-assessment } \\
\text { using VAS or on the basis of adverse } \\
\text { effects }\end{array}$ \\
\hline $\begin{array}{l}\text { Ogino } \\
{[22] / 2009}\end{array}$ & $\begin{array}{l}\text { Tenosy- } \\
\text { novitis }\end{array}$ & Open & 80 & 11 & Celecoxib 100 mg b.i.d. & $80 / 76 / 4$ & 2 & $\begin{array}{l}\text { Improvement rate/self-assessment } \\
\text { using VAS or on the basis of adverse } \\
\text { effects }\end{array}$ \\
\hline
\end{tabular}

A search of the Japan Medical Abstract Service ICHUSHI was performed to find clinical trials that compared the efficacy and safety of celecoxib with those of loxoprofen; we found 12 trials. All trials were different from each other in terms of the design, disease entity studied, drug administration, etc. All original articles were written in Japanese. 
Fig. 1. Efficacies of celecoxib and loxoprofen sodium in patients with RA in a clinical trial conducted in Japan [14]. A total of 771 patients with RA were randomly administered 12-week oral treatment with celecoxib (200 mg b.i.d.) or loxoprofen sodium (60 mg t.i.d.). The efficacy of celecoxib in terms of the rate of improvement in the patients was compared with that of loxoprofen. The rate of improvement was determined on the basis of the ACR improvement criteria [98].

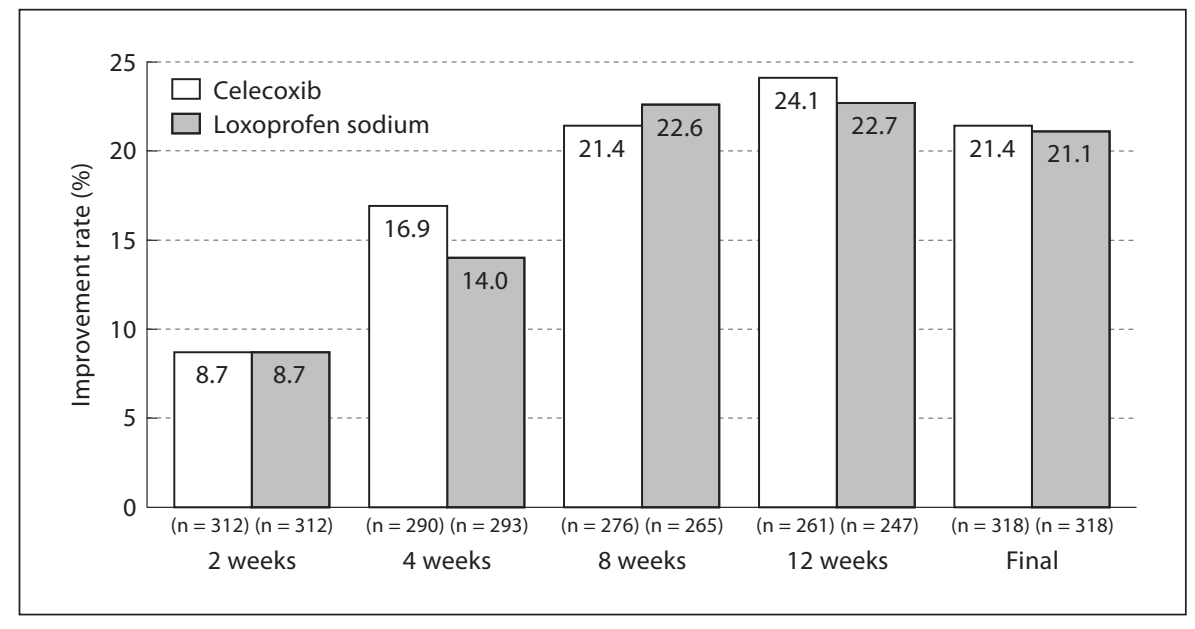

was significantly higher than that in the patients in the placebo group and was comparable to that in the patients in the loxoprofen sodium group (fig. 3). In addition to the assessment of pain using the VAS, the patients were assessed by the composite OA index (pain, stiffness, and physical function) developed by the Western Ontario McMaster Universities (WOMAC) (secondary endpoint). The scores revealed that the level of improvement in the patients in the celecoxib group was significantly higher than that in the patients in the placebo group and was comparable to that in the patients in the loxoprofen sodium group [17].

These data are also consistent with those of an overseas study in which the efficacy of celecoxib in a 6-week treatment regimen (100 $\mathrm{mg}$ b.i.d.) was compared to that of diclofenac (50 mg t.i.d.) or placebo [24].

These results indicated that in patients with OA, celecoxib can alleviate symptoms to a degree comparable to that achieved with loxoprofen sodium or diclofenac.

\section{Safety of Celecoxib}

\section{Upper GI Disorders}

Peptic ulcers in Japanese patients are mainly attributed to $H$. pylori infection. NSAID is the second most common cause of peptic ulcers in Japan, where the most commonly prescribed nonselective NSAID is loxoprofen. Loxoprofen produced by Daiichi-Sankyo and marketed in Japan since 1986 is a prodrug of propionic acid derivative that is activated in the liver, and it does not cause direct adverse reaction to the gastric mucosa. In fact, a double-blind controlled study in healthy Japanese volunteers

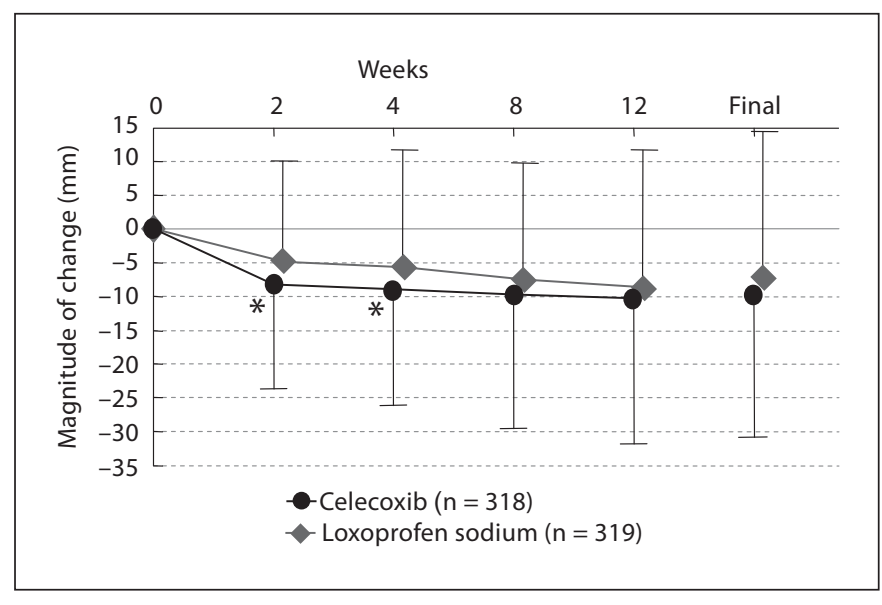

Fig. 2. Efficacies of celecoxib and loxoprofen sodium in patients with RA in a clinical trial conducted in Japan [14]. Joint pain was self-assessed by the patients using the VAS. The efficacy of celecoxib in terms of the scores reported by 771 patients was compared with that of loxoprofen. The VAS consists of a 100-mm horizontal or vertical line with 2 endpoints labeled 'no pain' and 'worst pain ever' (or similar verbal descriptions). Mean change \pm SD. ${ }^{*} \mathrm{p}<0.05$ [t test (significance level $=5 \%$, two-tailed) vs. loxoprofen sodium group].

revealed that subjects on loxoprofen had a significantly lower rate of gastric injury than those on diclofenac [25]. Another study on 1,206 Asian patients taking loxoprofen revealed that only $0.24 \%$ patients had GI bleeding and required hospitalization [26]. Therefore, loxoprofen is considered safe as compared to other nonselective NSAIDs such as indomethacin and diclofenac. A recent survey on the prescription of nonselective NSAIDs by 


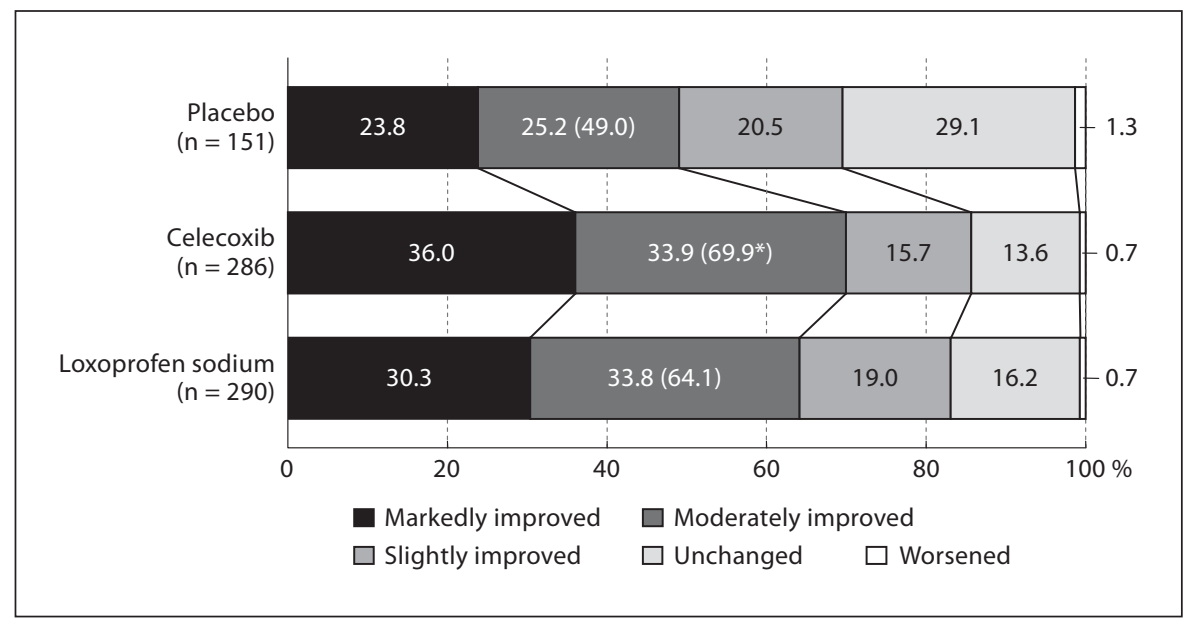

Fig. 3. Efficacies of celecoxib and loxoprofen sodium in patients with OA in a clinical trial conducted in Japan [17]. A total of 949 patients with OA were randomly administered 4-week oral treatment with celecoxib (100 mg b.i.d.), loxoprofen sodium (60 mg t.i.d.), or placebo. The efficacy of celecoxib in terms of the rate of improvement in the final global improvement assessment was compared with that of loxoprofen. The rate of improvement in the final global improvement assessment is a ratio of the number of subjects that were evaluated during the final global improvement assessment to the total number of subjects. The final global improvement assessment consists of 5 stages (stage $1=$ marked improvement; stage 2 = moderate improvement; stage $3=$ slight improvement; stage $4=$ no change, and stage $5=$ worsening of condition) based on global improvement assessment by doctors by using the VAS. Values in parentheses represent moderately or markedly improved cases. ${ }^{*} \mathrm{p}<0.05$ [Cochran-Mantel-Haenszel test (significance level $=5 \%$, two-tailed) vs. placebo group].

NSAIDs for 3 or more months [30]. In the recent and first epidemiological study in Japan [31], the risks of upper GI bleeding have been shown to be about 6 and 11 times higher, respectively, in subjects taking loxoprofen and diclofenac than in subjects not taking NSAIDs. Thus, the risk of upper GI bleeding for loxoprofen users was identified for the first time in this study. The striking finding of this study is that the odds ratio of loxoprofen was consistent with those of all other NSAIDs reported in case-control studies published in Western Europe since 2000 [32-42] (table 2). All these recent data suggest that NSAIDs, especially loxoprofen, which accounted for $87 \%$ of all NSAID prescriptions in Japan, is a cause of concern in terms of the treatment-associated gastroduodenal injuries.

Thus, the safety of celecoxib and loxoprofen in terms of GI injury was compared in 3 trials before celecoxib was approved by the government in Japan (table 1) [14, 17, 19]. The GI adverse effects observed in these 3 trials were combined and analyzed in 1,184 RA, OA, and low back pain patients taking celecoxib and 1,190 patients taking loxoprofen [43]. The results of this analysis indicated that the incidence of symptomatic gastroduodenal ulcers and hemorrhagic events (serious GI events) was significantly lower in the celecoxib $100-200 \mathrm{mg}$ b.i.d. group (0.1\%) than 
Table 2. Odds ratio or relative risk of upper GI bleeding in users of NSAIDs or individual NSAIDs

\begin{tabular}{|c|c|c|c|c|}
\hline $\begin{array}{l}\text { Authors/year } \\
\text { of publication }\end{array}$ & Country & $\begin{array}{l}\text { Study design and } \\
\text { number of cases }\end{array}$ & Odds ratio (OR) or Relative risk (RR) & Adjusted for medications \\
\hline $\begin{array}{l}\text { Hernández-Díaz } \\
\text { and } \\
\text { Rodríguez[32]/2000 }\end{array}$ & - & $\begin{array}{l}\text { Overview of } 18 \text { case-control studies } \\
\text { published between } 1990 \text { and } 1999 \\
\text { Total number of cases: } 12,552 \text {; total } \\
\text { number of controls: } 64,871\end{array}$ & Pooled RR = 3.8 & - \\
\hline $\begin{array}{l}\text { Stack } \\
\text { et al. [33]/2002 }\end{array}$ & UK & Cases: 203; controls: 203 & $\mathrm{OR}=10.6$ & - \\
\hline $\begin{array}{l}\text { Ofman } \\
\text { et al. [34]/2002 }\end{array}$ & - & $\begin{array}{l}16 \text { RCT } \\
23 \text { case-control studies } \\
9 \text { cohort studies }\end{array}$ & $\begin{array}{l}\text { Pooled OR of } 16 \text { RCTs }=5.36 \\
\text { Pooled OR of } 23 \text { case-control studies }=3.0 \\
\text { Pooled RR of } 9 \text { cohort studies }=2.7\end{array}$ & - \\
\hline $\begin{array}{l}\text { Lewis } \\
\text { et al. [35]/2002 }\end{array}$ & - & $\begin{array}{l}\text { Meta-analysis of } 3 \text { case-control } \\
\text { studies } \\
\text { Cases: } 2,472 \text {; controls: } 5,877\end{array}$ & $\begin{array}{l}\text { Ibuprofen: } \mathrm{OR}=1.7 ; \text { diclofenac: } \mathrm{OR}=4.9 ; \\
\text { indomethacin: } \mathrm{OR}=6.0 \text {; naproxen: } \mathrm{OR}=9.1 ; \\
\text { piroxicam: } \mathrm{OR}=13.1 ; \text { ketoprofen: } \mathrm{OR}=34.9\end{array}$ & - \\
\hline $\begin{array}{l}\text { Laporte } \\
\text { et al. [36]/2004 }\end{array}$ & $\begin{array}{l}\text { Spain, } \\
\text { Italy }\end{array}$ & $\begin{array}{l}\text { Case-control study } \\
\text { Cases: 2,813; controls: 7,193 }\end{array}$ & $\begin{array}{l}\text { Ketorolac: } \mathrm{OR}=24.7 ; \text { aceclofenac: } \mathrm{OR}=1.4 ; \\
\text { celecoxib: } \mathrm{OR}=0.3 \text {; dexketoprofen: } \mathrm{OR}=4.9 ; \\
\text { meloxicam: } \mathrm{OR}=5.7 ; \text { nimesulide: } \mathrm{OR}=3.2 ; \\
\text { rofecoxib: } \mathrm{OR}=7.2\end{array}$ & PPI, H2RA \\
\hline $\begin{array}{l}\text { Nórgård } \\
\text { et al. [37]/2004 }\end{array}$ & Denmark & $\begin{array}{l}\text { Case-control study } \\
\text { Cases: } 780 \text {; controls: } 2,906\end{array}$ & $\begin{array}{l}\text { NSAIDs: } \mathrm{OR}=3.3 \text {; celecoxib: } \mathrm{OR}=1.3 \\
\text { rofecoxib: } \mathrm{OR}=2.1\end{array}$ & PPI, H2RA \\
\hline $\begin{array}{l}\text { Tata } \\
\text { et al. [38]/2005 }\end{array}$ & UK & $\begin{array}{l}\text { Case-control study } \\
\text { Cases: } 11,261 \text {; controls: } 53,156\end{array}$ & NSAIDs: OR $=2.15$ & - \\
\hline $\begin{array}{l}\text { Hippisley-Cox } \\
\text { et al. [39]/2005 }\end{array}$ & UK & $\begin{array}{l}\text { Nested case-control study } \\
\text { Cases: 9,407; controls: } 88,867\end{array}$ & $\begin{array}{l}\text { Naproxen: } \mathrm{OR}=2.12 \text {; diclofenac: } \mathrm{OR}=1.96 \\
\text { rofecoxib: } \mathrm{OR}=1.56 \text {; celecoxib: } \mathrm{OR}=1.11\end{array}$ & - \\
\hline $\begin{array}{l}\text { Lanas } \\
\text { et al. }[40] / 2006\end{array}$ & Spain & $\begin{array}{l}\text { Cases-control study } \\
\text { Cases: 2,777; controls: } 5,532\end{array}$ & $\begin{array}{l}\text { NSAIDs: } \mathrm{RR}=5.3 ; \text { aceclofenac: } \mathrm{RR}=3.1 ; \\
\text { ketorolac: } \mathrm{RR}=14.4 \text {; rofecoxib: } \mathrm{RR}=2.1 ; \\
\text { celecoxib: } \mathrm{RR}=1.0\end{array}$ & $\begin{array}{l}\text { No adjustment } \\
\text { Present PPI users: } R R=0.62 \\
\text { Past PPI users: } R R=1.53 \\
\text { Present H2RA users: } R R=1.31 \\
\text { Past H2RA users: } R R=1.74\end{array}$ \\
\hline $\begin{array}{l}\text { García Rodríguez } \\
\text { et al. [41]/2007 }\end{array}$ & UK & $\begin{array}{l}\text { Nested case-control study } \\
\text { Cases: } 1,561 \text {; controls: } 10,000\end{array}$ & NSAIDs: $\mathrm{RR}=3.7$; coxibs: $\mathrm{RR}=2.6$ & Gastroprotectives \\
\hline $\begin{array}{l}\text { Helin-Salmivaara } \\
\text { et al. [42]/2007 }\end{array}$ & Finland & $\begin{array}{l}\text { Case-control study } \\
\text { Cases: } 9,191 \text {; controls: } 41,780\end{array}$ & $\begin{array}{l}\text { Meloxicam: } \mathrm{OR}=3.09 ; \text { naproxen: } \mathrm{OR}=2.61 \\
\text { ibuprofen: } \mathrm{OR}=1.58 ; \text { diclofenac: } \mathrm{OR}=3.22 \\
\text { celecoxib: } \mathrm{OR}=1.77 ; \text { rofecoxib: } \mathrm{OR}=2.66\end{array}$ & PPI, H2RA \\
\hline $\begin{array}{l}\text { Sakamoto } \\
\text { et al. [31]/2006 }\end{array}$ & Japan & $\begin{array}{l}\text { Case-control study } \\
\text { Cases: } 175 ; \text { controls: } 347\end{array}$ & $\begin{array}{l}\text { NSAIDs: } \mathrm{OR}=6.1 \text {; diclofenac: } \mathrm{OR}=10.9 \\
\text { loxoprofen: } \mathrm{OR}=5.5\end{array}$ & - \\
\hline
\end{tabular}

A Medline search for articles published between 2000 and 2008 was performed to search for the terms 'nonsteroidal anti-inflammatory drugs' and 'risk of GI bleeding'. The search was restricted to studies in adult humans and case-control studies or meta-analysis of case-control studies. RCT = Randomized-controlled trial.

in the loxoprofen sodium $60 \mathrm{mg}$ t.i.d. group $(0.7 \%$; $\mathrm{p}=$ 0.039 ) (table 3). This analysis was the first attempt to compare the frequency of serious GI event in subjects taking celecoxib and loxoprofen. With regard to the serious upper GI events, including symptomatic gastroduodenal ulcers and hemorrhagic events, celecoxib was safer than loxoprofen. However, the incidence of endoscopically confirmed gastroduodenal ulcers remains to be compared between subjects taking celecoxib and loxoprofen.

Celecoxib in the Treatment of $\mathrm{RA}$ and $\mathrm{OA}$
Thus far, many studies in the West have compared the safety of celecoxib to that of other NSAIDs such as diclofenac, ibuprofen, or naproxen. In these studies, the incidence of gastroduodenal ulcers and ulcer complications has been examined; the incidence of NSAID-associated gastroduodenal ulcers was confirmed by endoscopy as a surrogate marker of serious GI events (endoscopic trial) and NSAID-associated serious GI event rates including rates of symptomatic ulcers and complications of gastro- 
duodenal ulcers such as upper GI bleeding, perforation, and obstruction.

In an endoscopic trial involving 1,149 patients with RA [44], the incidence of endoscopically identified gastroduodenal ulcers was lower in the celecoxib group than in the naproxen group and comparable to that in the placebo group. In another celecoxib trial [23], 655 patients with RA were randomly assigned to celecoxib or diclofenac SR for 24 weeks; gastroduodenal ulcers were endo-

Table 3. Comparison of the incidences of symptomatic peptic ulcers and hemorrhagic events caused by celecoxib administration with those caused by loxoprofen sodium administration [43]

\begin{tabular}{|c|c|c|c|}
\hline & $\begin{array}{l}\text { Celecoxib } \\
(\mathrm{n}=1,184)\end{array}$ & $\begin{array}{l}\text { Loxoprofen sodium } \\
(\mathrm{n}=1,190)\end{array}$ & $\mathrm{p}$ \\
\hline $\begin{array}{l}\text { Incidences of } \\
\text { symptomatic } \\
\text { peptic ulcers and } \\
\text { hemorrhagic events } \\
\text { (total cases: } \\
\text { composition) }\end{array}$ & $\begin{array}{l}0.1 \% \text { ( } 1 \text { case: } \\
\text { gastric ulcer) }\end{array}$ & $\begin{array}{l}0.7 \% \text { ( } 8 \text { cases: gastric ulcer } \\
\text { in } 4 \text { cases, melena in } 1 \text { case, } \\
\text { GI hemorrhage in } 1 \text { case, } \\
\text { duodenal ulcer in } 1 \text { case, } \\
\text { hemorrhagic gastric ulcer } \\
\text { in } 1 \text { case) }\end{array}$ & 0.039 \\
\hline
\end{tabular}

On the basis of the data from the clinical studies conducted in Japan, the rates of the incidence of symptomatic peptic ulcers and hemorrhagic events in 2,374 patients with RA, OA, or low back pain for which a causal relationship to the drug was not ruled out were compared between the celecoxib (100-200 mg b.i.d.) group and the loxoprofen sodium (60 mg t.i.d.) group (combined analysis of data from all clinical studies in Japan). scopically detected in 33 (15.1\%) of 218 patients on diclofenac and $8(3.8 \%)$ of 212 patients on celecoxib ( $p<0.001)$. According to a Cochrane Collaboration systematic review, 5 [23,44-47] endoscopic studies on 2,439 patients comparing celecoxib with nonselective NSAIDs showed a $79 \%$ reduction in the relative risk of gastroduodenal ulcers (table 4) [48].

Instead of the selective COX-2 inhibitor, celecoxib, coadministration of proton pump inhibitor (PPI) with NSAID is an alternative therapy to prevent NSAID-related gastroduodenal ulcers. Many reports have suggested that PPI is effective in preventing NSAID-related endoscopically detected gastroduodenal ulcers [49-51]. Particularly, PPI is effective in preventing the relapse of NSAID-related gastroduodenal ulcers after healing in patients in whom NSAID treatment is maintained [51]. One meta-analysis published in 2004 clearly shows that coadministration of PPI with NSAID reduces the relative risk of gastroduodenal ulcers to 0.37 as compared to that of placebo [52].

In addition to these endoscopic trials, CLASS [53] and SUCCESS-I [54] studies involving 8,059 patients with RA or OA and 13,194 patients with OA, respectively, have shown that complications, including symptomatic ulcers and hemorrhagic events, were significantly more frequent in the nonselective NSAID group as compared to those in the celecoxib group. In comparison with meloxicam, celecoxib has a $44 \%$ lower risk of perforation or

Table 4. Comparison of the incidence of endoscopic ulcer in an RCT on celecoxib with that in RCTs on nonselective NSAIDs

\begin{tabular}{|c|c|c|c|c|c|c|c|c|}
\hline \multirow{2}{*}{$\begin{array}{l}\text { Authors/year } \\
\text { of publication }\end{array}$} & \multirow[t]{2}{*}{ Subject } & \multirow{2}{*}{$\begin{array}{l}\text { Term } \\
\text { weeks }\end{array}$} & \multicolumn{6}{|c|}{ Ulcer incidence } \\
\hline & & & $\begin{array}{l}\text { celecoxib } \\
100-400 \mathrm{mg} \mathrm{q}\end{array}$ & or b.i.d. & $\begin{array}{l}\text { diclofenac } \\
75 \text { mg b.i.d. }\end{array}$ & $\begin{array}{l}\text { ibuprofen } \\
800 \text { mg t.i.d. }\end{array}$ & $\begin{array}{l}\text { naproxen } \\
500 \mathrm{mg} \text { b.i.d. }\end{array}$ & placebo \\
\hline $\begin{array}{l}\text { Emery et al. } \\
{[23] / 1999}\end{array}$ & $\mathrm{RA}, \mathrm{n}=655$ & 24 & 200 mg b.i.d. & $3.8 \%(8 / 212)$ & $15.1 \%^{\mathrm{a}}(33 / 218)$ & & & \\
\hline $\begin{array}{l}\text { Simon et al. } \\
{[44] / 1999}\end{array}$ & $\mathrm{RA}, \mathrm{n}=1,149$ & 12 & $\begin{array}{l}100 \text { mg b.i.d. } \\
200 \text { mg b.i.d. } \\
400 \text { mg b.i.d. }\end{array}$ & $\begin{array}{l}6.1 \%(9 / 148) \\
4.1 \%(6 / 145) \\
6.2 \%(8 / 130)\end{array}$ & & & $\begin{array}{l}26.3 \% \\
(36 / 137)\end{array}$ & $\begin{array}{l}4.0 \% \\
(4 / 99)\end{array}$ \\
\hline $\begin{array}{l}\text { Goldstein et al. } \\
{[45] / 2001}\end{array}$ & $\mathrm{RA}$ or $\mathrm{OA}, \mathrm{n}=537$ & 12 & 200 mg b.i.d. & $9 \%$ & & & $41 \%$ & \\
\hline $\begin{array}{l}\text { Hawkey et al. } \\
{[46] / 2004}\end{array}$ & $\mathrm{OA}, \mathrm{n}=1,042$ & 13 & 200 mg q.d. & $\begin{array}{l}\text { Ulcer size }>3 \mathrm{~mm}: 3.2 \% \\
\text { Ulcer size }>5 \mathrm{~mm}: 2.8 \%\end{array}$ & & $\begin{array}{l}\text { Ulcer size }>3 \mathrm{~mm}: 15.7 \% \\
\text { Ulcer size }>5 \mathrm{~mm}: 12.5 \%\end{array}$ & & \\
\hline $\begin{array}{l}\text { Kivitz et al. } \\
{[47] / 2004}\end{array}$ & $\mathrm{RA}, \mathrm{n}=893$ & 13 & 200 mg b.i.d. & $1.9 \%$ & & $13.6 \%$ & & \\
\hline
\end{tabular}

Randomized control trials (RCT) comparing endoscopic ulceration of celecoxib with that of a nonselective NSAID or placebo were analyzed. ${ }^{a}$ Diclofenac SR. 
bleeding of the upper GI tract [55]. In a Cochrane Collaboration systematic review published in 2007 [48], 31,106 subjects were examined in 4 studies that assessed the effects of celecoxib and nonselective NSAIDs on serious clinical GI events (perforation, obstruction, or bleeding); the results of these studies showed that celecoxib was associated with a $77 \%$ reduction in the relative risk of serious GI events (RR 0.23; 95\% CI 0.07-0.76; random effects). These data suggest that celecoxib is safer than other conventional NSAIDs, because as compared to the latter, the former has a lower incidence of endoscopically confirmed gastroduodenal ulcers and lower rates of complications, including perforation, obstruction, and bleeding. This result is very important given the current situation where the effectiveness of PPI, which has been most commonly used to prevent NSAID-associated GI injury, for the primary prevention of NSAID-associated serious GI complications is yet to be examined. Because the focus of this study was to compare celecoxib data with those of loxoprofen in Japanese RA or OA patients, it is beyond the scope of this article to comment on the effects of PPI on NSAID-related gastroduodenal ulcers and the related complications. It is well known, however, that patients with a history of upper GI bleeding are at high risk of rebleeding even if PPI is coadministered with NSAIDs or if celecoxib is used [56]. Further, celecoxib with PPIs effectively reduced the incidence of bleeding from ulcers for 13 months in patients who had previously experienced bleeding from ulcers because of the use of NSAIDs [57]. Therefore, this combined therapy is a promising alternative for reducing the risk of upper GI disorders.

Because celecoxib has fewer adverse effects on the digestive tract, as illustrated above, the Guidelines on Management of Peptic Ulcers in Japan, edited by the Japanese Society of Gastroenterology [58], refer to selective COX-2 inhibitors as drugs that are endorsed as the best for preventing NSAID-associated GI injury.

\section{Risk for Cardiovascular Disorders}

As far as the cardiovascular (CV) risk is concerned, the results obtained thus far suggest that celecoxib would not cause serious adverse effects in Japanese subjects. In a combined analysis of the data of 2,410 patients on celecoxib and 1,190 patients on loxoprofen from 12 clinical studies conducted in Japan (table 1) [43], the incidence of serious CV events (0.1\%) in 2,398 subjects on celecoxib 25-400 mg b.i.d. did not differ significantly from the incidence in 1,190 subjects on loxoprofen sodium $60 \mathrm{mg}$ t.i.d. $(0.3 \% ; \mathrm{p}=0.3404)$ or placebo $(0.2 \%)$ as shown in table 5. On the other hand, according to the report on the VIGOR Study in 2000 involving patients with RA or OA [59], the CV risk after treatment with another selective COX-2 inhibitor, rofecoxib (not approved in Japan), was

Table 5. Comparison of the incidence of serious CV events caused by celecoxib with those caused by loxoprofen sodium [43]

\begin{tabular}{|c|c|c|c|c|c|c|}
\hline \multicolumn{2}{|c|}{ Adverse event (WHO-ART preferred terms) } & \multicolumn{2}{|l|}{$\begin{array}{l}\text { Celecoxib } \\
(n=2,398)\end{array}$} & \multicolumn{2}{|c|}{$\begin{array}{l}\text { Loxoprofen sodium } \\
(\mathrm{n}=1,190)\end{array}$} & \multirow[t]{2}{*}{$\mathrm{p}$} \\
\hline & & $\begin{array}{l}\text { number of cases } \\
\text { (incidence) }\end{array}$ & $\begin{array}{l}\text { number of } \\
\text { reactions }\end{array}$ & $\begin{array}{l}\text { number of cases } \\
\text { (incidence) }\end{array}$ & $\begin{array}{l}\text { number of } \\
\text { reactions }\end{array}$ & \\
\hline \multicolumn{2}{|l|}{ Serious CV events } & $2(0.1 \%)$ & 2 & $3(0.3 \%)$ & 5 & 0.3404 \\
\hline CV disorder (general) & Heart failure & 0 & 0 & $1(0.1 \%)$ & 1 & 0.0442 \\
\hline \multirow{3}{*}{$\begin{array}{l}\text { Myocardial, endocardial, } \\
\text { pericardial, and valvular disorders }\end{array}$} & Angina pectoris & 0 & 0 & $1(0.1 \%)$ & 1 & \\
\hline & Myocardial ischemia & 0 & 0 & $1(0.1 \%)$ & 1 & \\
\hline & Myocardial infarction & 0 & 0 & $1(0.1 \%)$ & 1 & \\
\hline \multirow[t]{2}{*}{ Vascular (extracardiac) disorders } & Cerebrovascular disease & $1(0.0 \%)$ & 1 & 0 & 0 & \\
\hline & Cerebral bleeding & 0 & 0 & $1(0.1 \%)$ & 1 & \\
\hline \multirow{2}{*}{$\begin{array}{l}\text { Platelet, hemorrhagic, and } \\
\text { clotting disorders }\end{array}$} & Thrombus (thrombosis) & $1(0.0 \%)$ & 1 & 0 & 0 & \\
\hline & Bleeding & 0 & 0 & 0 & 0 & \\
\hline
\end{tabular}

The incidence of serious CV events whose causal relationship to the drug was not ruled out was compared between the celecoxib (25-400 mg b.i.d.) group and the loxoprofen sodium $(60 \mathrm{mg}$ t.i.d.) group in 3,588 patients with $\mathrm{RA}, \mathrm{OA}$, or low back pain (com- bined analysis of data from all clinical studies in Japan). $\mathrm{p}$ value: Fisher's exact test. WHO-ART = World Health Organization's Adverse Reaction Terminology. 
Table 6. Risk of CV events in cohort studies on NSAIDs

\begin{tabular}{|c|c|c|c|c|c|}
\hline \multirow[t]{2}{*}{ Authors/year of publication } & \multicolumn{3}{|l|}{ Number } & \multicolumn{2}{|c|}{ Outcome evaluation } \\
\hline & $\begin{array}{l}\text { COX-2-selective inhibi- } \\
\text { tor (celecoxib, rofecoxib, } \\
\text { and valdecoxib) users }\end{array}$ & $\begin{array}{l}\text { nonselective } \\
\text { NSAID users }\end{array}$ & nonusers & & \\
\hline Solomon et al. [64]/2008 & 76,082 & 53,014 & 46,558 & Hazard ratio & $\begin{array}{l}\text { Myocardial infarction, stroke, congestive heart failure, } \\
\text { due to a } \mathrm{CV} \text { event } 6 \text { months before the evaluation }\end{array}$ \\
\hline Haag et al. $[65] / 2008$ & 7,636 & & & Hazard ratio & Stroke \\
\hline Rahme et al. [66]/2007 & 137,799 & 260,931 & 0 & Hazard ratio & Hospitalization for acute myocardial infarction \\
\hline Motsko et al. [67]/2006 & 2,096 & 10,092 & 0 & Hazard ratio & $\begin{array}{l}\text { Acute myocardial infarction, death due to coronary } \\
\text { heart disease, cerebrovascular event }\end{array}$ \\
\hline Huang et al. [68]/2006 & 5,312 & 4,290 & 0 & Hazard ratio & $\begin{array}{l}\text { Acute myocardial infarction } \\
\text { Angina } \\
\text { Stroke } \\
\text { Transient ischemic attack }\end{array}$ \\
\hline Hudson et al. [69]/2005 & 1,586 & 280 & 0 & Hazard ratio & Death, recurrent congestive heart failure \\
\hline Solomon et al. [70]/2006 & 47,393 & 27,445 & 23,532 & Rate ratio & $\begin{array}{l}\text { Myocardial infarction } \\
\text { Stroke }\end{array}$ \\
\hline Mamdani et al. [71]/2004 & 33,491 & 11,606 & 100,000 & Rate ratio & Congestive heart failure \\
\hline Mamdani et al. [72]/2003 & 27,427 & 39,537 & 100,000 & Rate ratio & Acute myocardial infarction \\
\hline Ray et al. [73]/2002 & 181,441 & & 181,441 & Rate ratio & $\begin{array}{l}\text { Acute myocardial infarction, death due to coronary } \\
\text { heart disease }\end{array}$ \\
\hline Ray et al. [74]/2002 & 46,469 & 129,391 & 202,916 & $\begin{array}{l}\text { Incidence } \\
\text { rate ratios }\end{array}$ & $\begin{array}{l}\text { Acute myocardial infarction, fatal coronary heart } \\
\text { disease }\end{array}$ \\
\hline Warner et al. [75]/2008 & 5,825 & 41,932 & 0 & Odds ratio & Acute myocardial infarction \\
\hline Schneeweiss et al. [76]/2006 & 32,074 & 17,637 & 0 & $\begin{array}{l}\text { Risk } \\
\text { differences }\end{array}$ & $\begin{array}{l}\text { Acute myocardial infarction (hospitalization in the first } \\
\text { or second position, hospital stay of at least } 4-180 \text { days) }\end{array}$ \\
\hline \multicolumn{4}{|c|}{$\begin{array}{l}\text { A Medline search of articles published between } 1999 \text { and } 2009 \text { was per- } \\
\text { formed to search for the terms 'nonsteroidal anti-inflammatory drugs', } \\
\text { 'cardiovascular risk', and 'epidemiology'. The search was restricted to stud- } \\
\text { ies on adult humans and case-control studies. Values in parentheses repre- } \\
\text { sent } 95 \% \text { confidence intervals. }\end{array}$} & \multicolumn{2}{|c|}{$\begin{array}{l}{ }^{a} \text { Acetaminophen. }{ }^{b} \text { Etodolac. }{ }^{c} \text { Valdecoxib. }{ }^{\mathrm{d}} \text { Diflunisal, etodolac, feno- } \\
\text { ofen, flurbiprofen, indomethacin, ketoprofen, ketorolac, meclofenamate, } \\
\text { efenamic acid, meloxicam, nabumetone, oxaprozin, piroxicam, sulindac, } \\
\text { d tolmetin. }{ }^{\mathrm{e}} \text { Diclofenac plus misoprostol, naproxen, ibuprofen, or diclo- } \\
\text { nac. }{ }^{\mathrm{f}} \text { Nonnaproxen nonselective NSAIDs. }\end{array}$} \\
\hline
\end{tabular}

2.4 times higher than the CV risk after treatment with naproxen.

In a subsequent study on the prevention of colorectal polyp recurrence (the APPROVe Trial [60]), the CV risk was 1.96-fold that of placebo when rofecoxib treatment period exceeded 18 months. On the basis of these results, Merck (USA) discontinued the distribution of rofecoxib and voluntarily recalled the product. One study (the APC Study [61]) revealed that celecoxib elevated the $\mathrm{CV}$ risk when used at high doses and for long periods of time. The results of other randomized controlled trials (the PreSAP Trial [62] and the ADAPT [63]) similar to
APC Study, however, showed that the CV risk with celecoxib was comparable to that with placebo or conventional NSAIDs. On the basis of the available evidence, the Advisory Committee of the Food and Drug Administration (FDA) reported that the benefits of celecoxib outweighed its risks. In subsequent epidemiological analysis that investigated whether $\mathrm{CV}$ events were related to NSAID usage, conventional NSAIDs were found to elevate $\mathrm{CV}$ risk, while the risk due to celecoxib was identified in only 1 out of 17 studies (table 6 [64-76], table 7 [77-91]). Thus, the FDA judged that the CV risk is not related to the class effect of selective COX-2 in- 


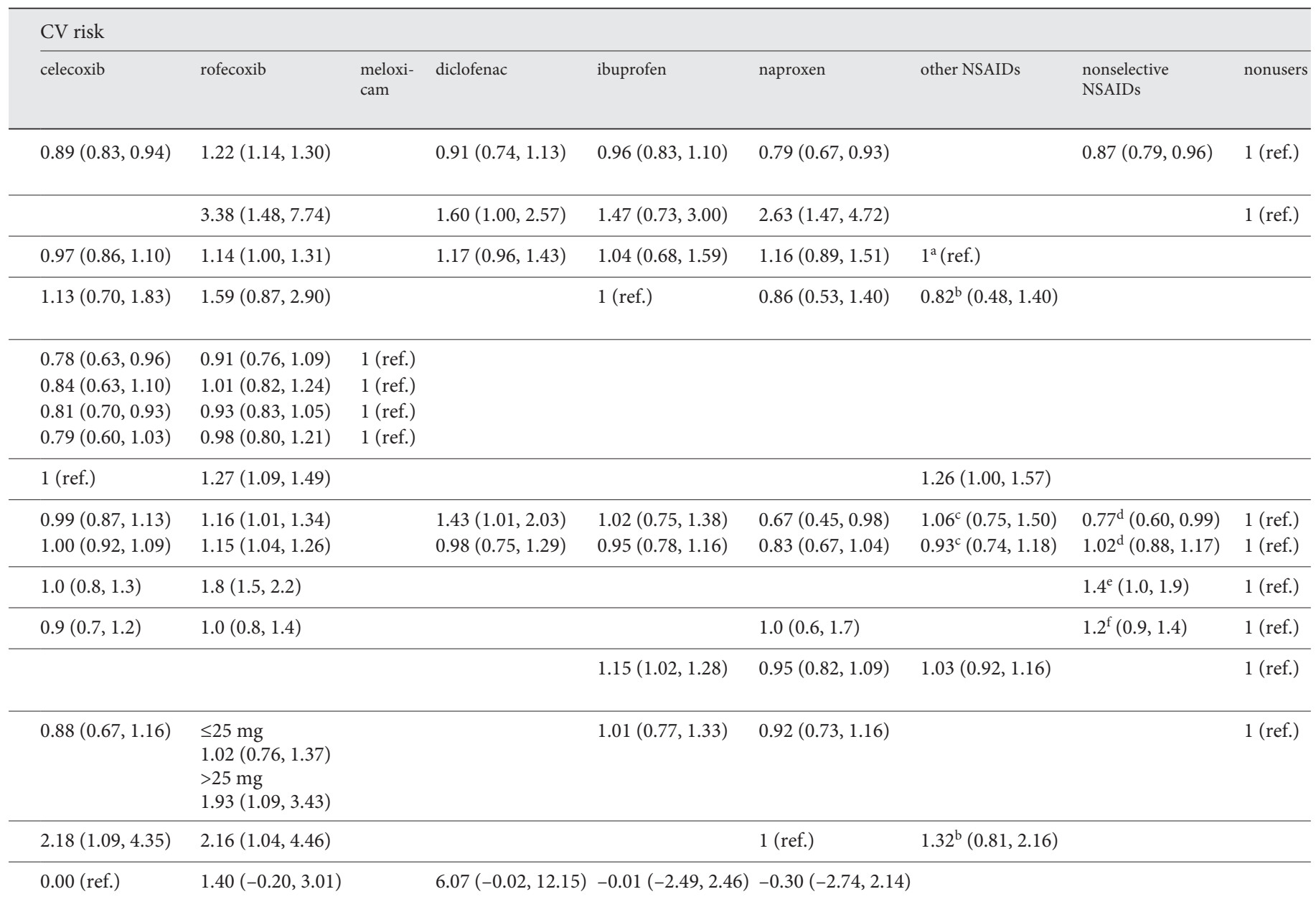

hibitors. Thereafter, the FDA required that all pharmaceutical companies should add a warning regarding $\mathrm{CV}$ and GI bleeding risks on the package insert of all NSAIDs, except aspirin.

Therefore, all NSAIDs should be used with caution or avoided when possible, especially in subjects who have a history of CV events, although the incidence of ischemic heart disease is lower in Japanese and Korean populations than in Western populations according to the Organization for Economic Co-operation and Development (OECD) data [92].

Celecoxib in the Treatment of $\mathrm{RA}$ and $\mathrm{OA}$

\section{Renal Disorders}

Inhibition of PG synthesis in the kidney may result in edema and elevated blood pressure. PGs have been shown to be synthesized in the kidney through a mechanism mediated by both COX-1 and COX-2. Therefore, both NSAIDs and selective COX-2 inhibitors are likely to decrease PG synthesis in the kidney. However, in a combined analysis of the data from 3 studies conducted in Japan [43], the incidence of adverse events associated with edema was significantly lower in the celecoxib treatment group than in the loxoprofen sodium group. Furthermore, the magnitude of change in the systolic and dia- 
Table 7. Risk of CV events in case-control studies on NSAIDs

\begin{tabular}{|c|c|c|c|c|c|}
\hline \multirow[t]{2}{*}{ Authors/year of publication } & \multirow[t]{2}{*}{ Nested } & \multicolumn{2}{|c|}{ Number } & \multicolumn{2}{|c|}{ Outcome evaluation } \\
\hline & & cases & controls & & \\
\hline Varas-Lorenzo et al. [77]/2009 & Yes & 3,252 & 20,002 & Odds ratio & Acute myocardial infarction \\
\hline Andersohn et al. [78]/2006 & Yes & 3,094 & 11,859 & Odds ratio & Ischemic stroke \\
\hline Kimmel et al. [79]/2005 & No & 1,718 & 6,800 & Odds ratio & Nonfatal myocardial infarction \\
\hline Graham et al. [80]/2005 & Yes & 8,143 & 31,496 & Odds ratio & Acute myocardial infarction \\
\hline
\end{tabular}

\begin{tabular}{llllll}
\hline Hippisley-Cox and Coupland [81]/2005 & Yes & 9,218 & 86,349 & Odds ratio & Myocardial infarction \\
\hline Fischer et al. [82]/2005 & No & 8,688 & 33,923 & Odds ratio & Acute myocardial infarction \\
\hline Solomon et al. [83]/2004 & No & 10,895 & 43,580 & Odds ratio & Acute myocardial infarction
\end{tabular}

\begin{tabular}{|c|c|c|c|c|c|}
\hline García Rodríguez et al. [84]/2004 & Yes & 4,975 & 20,000 & Odds ratio & Acute myocardial infarction, death due to coronary heart disease \\
\hline Bak et al. [85]/2003 & Yes & $\begin{array}{l}659 \\
2,717\end{array}$ & 40,000 & Odds ratio & $\begin{array}{l}\text { Intracerebral hemorrhage } \\
\text { Ischemic stroke }\end{array}$ \\
\hline Schlienger et al. [86]/2002 & No & 3,319 & 13,139 & Odds ratio & Acute myocardial infarction \\
\hline Watson et al. [87]/2002 & No & 809 & 2,285 & Odds ratio & Myocardial infarction, sudden death, stroke \\
\hline Huerta et al. [88]/2006 & Yes & 1,396 & 5,000 & Relative risk & Hospitalization for heart failure \\
\hline $\begin{array}{l}\text { García Rodríguez and González-Pérez } \\
\text { [89]/2005 }\end{array}$ & Yes & 4,975 & 20,000 & Relative risk & Acute myocardial infarction \\
\hline Johnsen et al. [90]/2005 & No & 10,280 & 102,797 & Relative risk & Hospitalization for myocardial infarction \\
\hline Brophy et al. [91]/2007 & Yes & 3,423 & 68,456 & Rate ratio & Acute myocardial infarction \\
\hline
\end{tabular}

A Medline search of articles published between 1999 and 2009 was performed to search for the terms 'nonsteroidal antiinflammatory drugs', 'cardiovascular risk', and 'epidemiology'. The search was restricted to studies on adult humans and case-control studies. Values represent $95 \%$ confidence intervals.

a Meloxicam, etoricoxib, etodolac, and valdecoxib. ${ }^{\text {b }}$ Other nonselective NSAIDs. ${ }^{c}$ Etodolac, tiaprofenic acid, ketoprofen, tenoxicam, nabumetone, diclofenac combination, tolfenamic acid, meloxicam, sulindac, aceklofenac, flurbiprofen, tolmetin, phenylbutazone, azapropazone, dexibuprofen, fenbufen, and proquazone. ${ }^{\mathrm{d}}$ Aceclofenac, acemetacin, azapropazone, etodolac, fenbufen, fenoprofen, flurbiprofen, mefenamic acid, nabumetone, tenoxicam, tiaprofenic acid, and sulindac. e Other COX-2-selective inhibitor NSAIDs. ${ }^{\mathrm{f}}$ Nonaspirin NSAIDs. 


\begin{tabular}{|c|c|c|c|c|c|c|c|c|c|c|}
\hline \multicolumn{11}{|l|}{$\mathrm{CV}$ risk } \\
\hline $\begin{array}{l}1.07 \\
(0.79,1.44)\end{array}$ & $\begin{array}{l}1.71 \\
(1.33,2.18)\end{array}$ & & $\begin{array}{l}1.32 \\
(1.10,1.57)\end{array}$ & $\begin{array}{l}1.12 \\
(0.91,1.37)\end{array}$ & $\begin{array}{l}1.16 \\
(0.80,1.70)\end{array}$ & & & $\begin{array}{l}1.20 \\
(1.02,1.40)\end{array}$ & & $\begin{array}{l}1 \\
\text { (ref.) }\end{array}$ \\
\hline $\begin{array}{l}0.84 \\
(0.67,1.04)\end{array}$ & $\begin{array}{l}\leq 25 \mathrm{mg} \\
1.23(0.89,1.71) \\
>25 \mathrm{mg} \\
3.00(1.09,8.31)\end{array}$ & & & $\begin{array}{l}1.06 \\
(0.96,1.17)\end{array}$ & $\begin{array}{l}1.14 \\
(1.00,1.30)\end{array}$ & & & $\begin{array}{l}1.13 \\
(1.01,1.27)\end{array}$ & & $\begin{array}{l}1 \\
\text { (ref.) }\end{array}$ \\
\hline $\begin{array}{l}1 \\
\text { (ref.) }\end{array}$ & $\begin{array}{l}\leq 25 \mathrm{mg} \\
1.47(0.99,2.17) \\
>25 \mathrm{mg} \\
3.58(1.27,10.11)\end{array}$ & & & $\begin{array}{l}1.26 \\
(1.00,1.60)\end{array}$ & $\begin{array}{l}1.36 \\
(1.06,1.75)\end{array}$ & & & $\begin{array}{l}1.35 \\
(1.06,1.72)\end{array}$ & & \\
\hline $\begin{array}{l}1.21 \\
(0.96,1.54)\end{array}$ & & & $\begin{array}{l}1.23 \\
(1.00,1.51)\end{array}$ & $\begin{array}{l}1.16 \\
(0.92,1.46)\end{array}$ & $\begin{array}{l}0.96 \\
(0.66,1.38)\end{array}$ & $\begin{array}{l}1.36 \\
(0.82,2.25)\end{array}$ & $\begin{array}{l}0.95 \\
(0.53,1.69)\end{array}$ & & & $\begin{array}{l}1 \\
\text { (ref.) }\end{array}$ \\
\hline $\begin{array}{l}1 \\
\text { (ref.) } \\
0.93 \\
(0.84,1.02) \\
0.95 \\
(0.74,1.21) \\
0.98 \\
(0.76,1.26) \\
0.95 \\
(0.82,1.10)\end{array}$ & $\begin{array}{l}1.24 \\
(1.05,1.46) \\
1.14 \\
(1.00,1.31) \\
1.17 \\
(0.90,1.52) \\
1.21 \\
(0.92,1.58) \\
1.17 \\
(0.99,1.38)\end{array}$ & & & $\begin{array}{l}1 \\
\text { (ref.) }\end{array}$ & $\begin{array}{l}1 \\
\text { (ref.) }\end{array}$ & & & $\begin{array}{l}1 \\
\text { (ref.) }\end{array}$ & & $\begin{array}{l}1 \\
\text { (ref.) }\end{array}$ \\
\hline \multirow{4}{*}{$\begin{array}{l}0.95 \\
(0.82,1.10)\end{array}$} & & & $\begin{array}{l}1.38 \\
(1.08,1.77)\end{array}$ & $\begin{array}{l}1.17 \\
(0.87,1.58)\end{array}$ & $\begin{array}{l}0.68 \\
(0.42,1.13)\end{array}$ & $\begin{array}{l}1.03 \\
(0.58,1.85)\end{array}$ & $\begin{array}{l}1.65 \\
(0.78,3.49)\end{array}$ & & & $\begin{array}{l}1 \\
\text { (ref.) }\end{array}$ \\
\hline & & & & & $\begin{array}{l}0.61 \\
(0.39,0.94)\end{array}$ & & & & & $\begin{array}{l}1 \\
\text { (ref.) }\end{array}$ \\
\hline & & $\begin{array}{l}0.66 \\
(0.24,1.83)\end{array}$ & $\begin{array}{l}1.08 \\
(0.76,1.52)\end{array}$ & $\begin{array}{l}1.43 \\
(1.01,2.02)\end{array}$ & $\begin{array}{l}2.01 \\
(1.08,3.74)\end{array}$ & $\begin{array}{l}3.39 \\
(1.50,7.67)\end{array}$ & $\begin{array}{l}1.38 \\
(0.58,3.28)\end{array}$ & $\begin{array}{l}1.42^{\mathrm{d}} \\
(0.76,2.68)\end{array}$ & & $\begin{array}{l}1 \\
\text { (ref.) }\end{array}$ \\
\hline & & & $\begin{array}{l}1.17 \\
(0.98,1.40)\end{array}$ & $\begin{array}{l}1.05 \\
(0.86,1.28)\end{array}$ & $\begin{array}{l}0.89 \\
(0.64,1.25)\end{array}$ & & & & & $\begin{array}{l}1 \\
\text { (ref.) }\end{array}$ \\
\hline $\begin{array}{l}1.25 \\
(0.97,1.62)\end{array}$ & $\begin{array}{l}1.80 \\
(1.47,2.21)\end{array}$ & & & & $\begin{array}{l}1.50 \\
(0.99,2.29)\end{array}$ & & & $\begin{array}{l}1.45^{\mathrm{e}} \\
(1.09,1.93)\end{array}$ & $\begin{array}{l}1.68^{\mathrm{f}} \\
(1.52,1.85)\end{array}$ & $\begin{array}{l}1 \\
\text { (ref.) }\end{array}$ \\
\hline $\begin{array}{l}1.08 \\
(0.94,1.25)\end{array}$ & $\begin{array}{l}1.28 \\
(1.10,1.49)\end{array}$ & $\begin{array}{l}0.78 \\
(0.36,1.68)\end{array}$ & & & $\begin{array}{l}1.24 \\
(0.83,1.84)\end{array}$ & & & & $\begin{array}{l}1.00^{\mathrm{f}} \\
(0.75,1.34)\end{array}$ & $\begin{array}{l}1 \\
\text { (ref.) }\end{array}$ \\
\hline
\end{tabular}


stolic blood pressure was also significantly smaller in the celecoxib group than in the loxoprofen sodium group. These data are consistent with the results of the CLASS study [93], where the magnitude of change in serum creatinine level and creatinine clearance from the pretreatment baseline level was shown to be smaller in the celecoxib treatment group than in the diclofenac or ibuprofen treatment groups in patients with RA or OA. Taken together, these results suggest that the impact of celecoxib on the kidneys is relatively small.

\section{Positioning of Celecoxib in Guidelines}

Often RA treatment is based on the ACR guidelines published in 2002 [94] and the disease activity score recommended by the European League Against Rheumatism (EULAR). The Diagnostic Manual and EBM-Based Treatment Guidelines were published in 2004 by the Japan Rheumatism Foundation (JRF) [95]. A basic approach to RA treatment is to suppress the progression of bone/cartilage destruction and improve long-term prognosis through treatment with antirheumatic drugs, biologic agents, etc., while maintaining the quality of life of patients with the use of NSAIDs and steroids [95]. In both the ACR and JRF guidelines, NSAIDs are deemed as the drugs that are recommended to be used from the early phases of treatment to control inflammation and pain. However, NSAIDs do not appear to have any effect in preventing articular destruction; NSAIDs are administered as the auxiliary treatment to alleviate the symptoms.

The Osteoarthritis Research Society International (OARSI) published its guidelines on the treatment of OA in 2 parts, part I and II, in 2007 and 2008, respectively. In part I [96], the published papers on the effects of selective COX-2 inhibitors, NSAIDs + PPIs, and NSAIDs + misoprostol for OA treatment were grouped as category Ia with the highest evidence level (meta-analysis, randomized comparative study), and their recommendation rate was $100 \%$. In part II [97], it was recommended that NSAIDs should be used at the minimum effective dose for the treatment of OA, while avoiding prolonged use; patients at an elevated risk for GI disorders should be treated with a combination of a selective COX-2 inhibitor or NSAID + PPI or misoprostol, and these drugs were to be used with particular care in patients with CV risk factors.

\section{Conclusion}

In this review, we overviewed the data of the Japanese trials that compared the efficacy and safety of celecoxib with those of loxoprofen and compared the celecoxib trial data with those of celecoxib trials published in the West. We also evaluated the safety and usefulness of celecoxib in Japanese subjects with RA, OA, or low back pain. Loxoprofen is a well-known fast-acting analgesic agent and is known to be fairly safe because of its nature of a prodrug, and not similar to those of other NSAIDs that may directly harm the gastric mucosa; therefore, loxoprofen is widely prescribed in Asia. However, in the trials conducted in Japan, with regard to self-assessment of pain by RA patients, celecoxib induced more rapid improvement than loxoprofen, thereby suggesting that celecoxib is more than equivalent to loxoprofen in terms of efficacy. With regard to GI injury that may usually develop in long-term NSAID users, the rates of incidences of symptomatic ulcers and hemorrhagic events in patients treated with celecoxib were significantly lower than the corresponding rates in patients treated with loxoprofen. In addition, the rate of occurrence of CV events in subjects treated with celecoxib was comparable to those in subjects treated with loxoprofen and placebo. All these data are consistent with those reported in the West, thereby suggesting that the use of celecoxib is preferred over conventional NSAIDs like loxoprofen to prevent NSAIDassociated GI injury, which still remains highly prevalent and unchanged in Japan.

\section{Disclosure Statement}

The authors disclose the following: Prof. Sakamoto received a grant and research support from Takeda Pharmaceuticals Co., Ltd., Otsuka Pharmaceuticals Co., Ltd., Eisai Co., Ltd., Astellas Pharma Inc., and AstraZeneca. Prof. Sakamoto also received compensation as a speaker and instructor from Eisai Co., Ltd. and Otsuka Pharmaceutical Co., Ltd.

Prof. Soen received a grant and research support from Merck \& Co., Inc., Teijin Pharma Ltd., Takeda Pharmaceuticals Co., Ltd., Eisai Co., Ltd., Chugai Pharmaceutical Co., Ltd., Eli Lilly Japan Co., Ltd., Daiichi Sankyo Co., Ltd., Pfizer Japan Inc., Mitsubishi Tanabe Pharma Co., Ltd., and Sanofi Aventis Co., Ltd. Prof. Soen also received compensation as a speaker and instructor from Bristol-Myers Squibb Co., Ltd. and Santen Pharmaceutical Co., Ltd. 


\section{References}

$\checkmark 1$ FitzGerald GA: COX-2 and beyond: approaches to prostaglandin inhibition in human disease. Nat Rev Drug Discov 2003;2: 879-890.

$\checkmark 2$ DeWitt DL, Smith WL: Primary structure of prostaglandin $\mathrm{G} / \mathrm{H}$ synthase from sheep vesicular gland determined from the complementary DNA sequence. Proc Natl Acad Sci USA 1988;85:1412-1416.

3 Xie WL, Chipman JG, Robertson DL, Erikson RL, Simmons DL: Expression of a mitogen-responsive gene encoding prostaglandin synthase is regulated by mRNA splicing. Proc Natl Acad Sci USA 1991;88:2692-2696.

4 Seibert K, Zhang Y, Leahy K, Hauser S, Masferrer J, Perkins W, Lee L, Isakson P: Pharmacological and biochemical demonstration of the role of cyclooxygenase 2 in inflammation and pain. Proc Natl Acad Sci USA 1994; 91:12013-12017.

$\checkmark 5$ Whelton A: Nephrotoxicity of nonsteroidal anti-inflammatory drugs: physiologic foundations and clinical implications. Am J Med 1999; 106:13S-24S.

-6 O’Banion MK, Winn VD, Young DA: cDNA cloning and functional activity of a glucocorticoid-regulated inflammatory cyclooxygenase. Proc Natl Acad Sci USA 1992;89: 4888-4892.

7 Hempel SL, Monick MM, Hunninghake GW: Lipopolysaccharide induces prostaglandin $\mathrm{H}$ synthase- 2 protein and mRNA in human alveolar macrophages and blood monocytes. J Clin Invest 1994;93:391-396.

$>8$ Masferrer JL, Zweifel BS, Manning PT, Hauser SD, Leahy KM, Smith WG, Isakson PC, Seibert K: Selective inhibition of inducible cyclooxygenase 2 in vivo is antiinflammatory and nonulcerogenic. Proc Natl Acad Sci USA 1994;91:3228-3232.

$\checkmark 9$ Iseki S: Immunocytochemical localization of cyclooxygenase- 1 and cyclooxygenase- 2 in the rat stomach. Histochem J 1995;27:323328.

-10 Singh G: Recent considerations in nonsteroidal anti-inflammatory drug gastropathy. Am J Med 1998;105:31S-38S.

-11 Kurumbail RG, Stevens AM, Gierse JK, McDonald JJ, Stegeman RA, Pak JY, Gildehaus D, Miyashiro JM, Penning TD, Seibert K, Isakson PC, Stallings WC: Structural basis for selective inhibition of cyclooxygenase- 2 by anti-inflammatory agents. Nature 1996; 384:644-648

-12 Asaka M, Kimura T, Kudo M, Takeda H, Mitani S, Miyazaki T, Miki K, Graham DY: Relationship of Helicobacter pylori to serum pepsinogens in an asymptomatic Japanese population. Gastroenterology 1992;102: 760-766.
13 Abe T, Saito T, Hashimoto H, Nagaya I, Ozaki S, Inoue H, Eguchi K, Azuma T, Kusunoki T (in Japanese). Prog Med 2006;26(suppl 3): 2788-2819.

14 Abe T, Saito T, Hashimoto H, Nagaya I, Eguchi K, Azuma T, Kusunoki T (in Japanese). Prog Med 2006;26(suppl 3):2820-2845.

15 Azuma T (in Japanese). Prog Med 2006; 26(suppl 3):2846-2868.

16 Aoki T, Moriya H, Sakuma A, Sugawara S Matsui N, Nagaya I, Komatsubara Y, Kokubun S, Fujii K, Inoue H, Iwamoto Y (in Japanese). Prog Med 2006;26(suppl 3):28692910.

17 Sugawara S (in Japanese). Prog Med 2006;26 (suppl 3):2911-2931.

18 Sugawara S (in Japanese). Prog Med 2006 26(suppl 3):2932-2952.

19 Kikuchi S, Yamazaki S, Nakamura H, Hatsuzawa J, Hosoe H (in Japanese). Prog Med 2009;29(suppl 2):2853-2872.

20 Takagishi K (in Japanese). Prog Med 2009; 29(suppl 2):2893-2917.

21 Takagishi K (in Japanese). Prog Med 2009; 29(suppl 2):2918-2940.

22 Ogino T (in Japanese). Prog Med 2009;29 (suppl 2):2941-2963.

23 Emery P, Zeidler H, Kvien TK, Guslandi M, Naudin R, Stead H, Verburg KM, Isakson PC, Hubbard RC, Geis GS: Celecoxib versus diclofenac in long-term management of rheumatoid arthritis: randomised doubleblind comparison. Lancet 1999;354:21062111.

24 McKenna F, Borenstein D, Wendt H, Wallemark C, Lefkowith JB, Geis GS: Celecoxib versus diclofenac in the management of osteoarthritis of the knee. Scand J Rheumatol 2001;30:11-18

25 Yanagawa A, Fukumura T, Matsui H, Uemura $\mathrm{H}$, Endo $\mathrm{T}$, Nakagawa $\mathrm{T}$, Mizushima $\mathrm{Y}$ Possible mechanisms of gastroduodenal mucosal damage in volunteers treated with nonsteroidal antiinflammatory drugs - the usefulness of prodrugs. J Rheumatol 1992;19: 1075-1082.

26 Waikakul S, Waikakul W: A post marketing survey on the side-effects of loxoprofen. J Med Assoc Thai 1999;82:721-726.

27 Arakawa T, Fujiwara Y, Sollano JD, Zhu Q, Kachintorn U, Rani AA, Hahm KB, Takahashi S, Joh T, Kinoshita Y, Matsumoto T, Naito Y, Takeuchi K, Yamagami H, Agustanti N, Xiong H, Chen X, Jang EJ, Furuta K, Terano A, IGICS study group: A questionnaire-based survey on the prescription of non-steroidal anti-inflammatory drugs by physicians in East Asian countries in 2007. Digestion 2009;79:177-185.

-28 Shiokawa Y, Nobunaga M, Saito T, Asaki S, Ogawa N: Epidemiology study on upper gastrointestinal lesions induced by non-steroidal anti-inflammatory drugs (in Japanese) Ryumachi 1991;31:96-111.
29 Yajima H, Yamao J, Miyauchi Y, Ono H, Akiyama K, Sakurai G, Kikuchi E, Matsumoto M, Nakayama M, Ann T, Kojima H, Mitoro A, Yoshida M, Yoshikawa M, Fukui H, Takakura Y: Most up to date information on gastric mucosallesions bylong-term NSAIDs therapy (in Japanese). Ther Res 2006;27: 1211-1217.

-30 Miyake K, Kusunoki M, Shinji Y, Shindo T, Kawagoe T, Futagami S, Gudis K, Tsukui T, Nakajima A, Sakamoto C: Bisphosphonate increases risk of gastroduodenal ulcer in rheumatoid arthritis patients on long-term nonsteroidal antiinflammatory drug therapy. J Gastroenterol 2009;44:113-120.

-31 Sakamoto C, Sugano K, Ota S, Sakaki N, Takahashi S, Yoshida Y, Tsukui T, Osawa H, Sakurai Y, Yoshino J, Mizokami Y, Mine T, Arakawa T, Kuwayama H, Saigenji K, Yakabi K, Chiba T, Shimosegawa T, Sheehan JE, Perez-Gutthann S, Yamaguchi T, Kaufman DW, Sato T, Kubota K, Terano A: Case-control study on the association of upper gastrointestinal bleeding and nonsteroidal anti-inflammatory drugs in Japan. Eur J Clin Pharmacol 2006;62:765-772.

>32 Hernández-Díaz S, Rodríguez LA: Association between nonsteroidal anti-inflammatory drugs and upper gastrointestinal tract bleeding/perforation: an overview of epidemiologic studies published in the 1990s. Arch Intern Med 2000;160:2093-2099.

>33 Stack WA, Atherton JC, Hawkey GM, Logan RF, Hawkey CJ: Interactions between Helicobacter pylori and other risk factors for peptic ulcer bleeding. Aliment Pharmacol Ther 2002;16:497-506

34 Ofman JJ, MacLean CH, Straus WL, Morton SC, Berger ML, Roth EA, Shekelle P: A metaanalysis of severe upper gastrointestinal complications of nonsteroidal antiinflammatory drugs. J Rheumatol 2002;29:804812 .

35 Lewis SC, Langman MJ, Laporte JR, Matthews JN, Rawlins MD, Wiholm BE: Doseresponse relationships between individual nonaspirin nonsteroidal anti-inflammatory drugs (NANSAIDs) and serious upper gastrointestinal bleeding: a meta-analysis based on individual patient data. Br J Clin Pharmacol 2002;54:320-326.

>36 Laporte JR, Ibáñez L, Vidal X, Vendrell L, Leone R: Upper gastrointestinal bleeding associated with the use of NSAIDs: newer versus older agents. Drug Saf 2004;27:411-420.

37 Nørgård B, Pedersen L, Johnsen SP, Tarone RE, McLaughlin JK, Friis S, Sørensen HT: COX-2-selective inhibitors and the risk of upper gastrointestinal bleeding in high-risk patients with previous gastrointestinal diseases: a population-based case-control study. Aliment Pharmacol Ther 2004;19:817-825. 
-38 Tata LJ, Fortun PJ, Hubbard RB, Smeeth L, Hawkey CJ, Smith CJ, Whitaker HJ, Farrington $\mathrm{CP}$, Card TR, West J: Does concurrent prescription of selective serotonin reuptake inhibitors and non-steroidal antiinflammatory drugs substantially increase the risk of upper gastrointestinal bleeding? Aliment Pharmacol Ther 2005;22:175-181.

>39 Hippisley-Cox J, Coupland C, Logan R: Risk of adverse gastrointestinal outcomes in patients taking cyclo-oxygenase- 2 inhibitors or conventional non-steroidal anti-inflammatory drugs: population based nested casecontrol analysis. BMJ 2005;331:1310-1316.

-40 Lanas A, García-Rodríguez LA, Arroyo MT, Gomollón F, Feu F, González-Pérez A, Zapata E, Bástida G, Rodrigo L, Santolaria S, Güell M, de Argila CM, Quintero E, Borda F, Piqué JM, Asociación Española de Gastroenterología: Risk of upper gastrointestinal ulcer bleeding associated with selective cyclo-oxygenase-2 inhibitors, traditional non-aspirin non-steroidal anti-inflammatory drugs, aspirin and combinations. Gut 2006;55:1731-1738.

41 García Rodríguez LA, Barreales Tolosa L: Risk of upper gastrointestinal complications among users of traditional NSAIDs and COXIBs in the general population. Gastroenterology 2007;132:498-506.

-42 Helin-Salmivaara A, Saarelainen S, Grönroos JM, Vesalainen R, Klaukka T, Huupponen R: Risk of upper gastrointestinal events with the use of various NSAIDs: a case-control study in a general population. Scand J Gastroenterol 2007;42:923-932. www.info. pmda.go.jp/shinyaku/g070106/index.html

43 Pharmaceuticals and Medical Devices Agency. Celecoxib assessment report, 2006.

-44 Simon LS, Weaver AL, Graham DY, Kivitz AJ, Lipsky PE, Hubbard RC, Isakson PC, Verburg KM, Yu SS, Zhao WW, Geis GS: Anti-inflammatory and upper gastrointestinal effects of celecoxib in rheumatoid arthritis: a randomized controlled trial. JAMA 1999; 282:1921-1928.

45 Goldstein JL, Correa P, Zhao WW, Burr AM, Hubbard RC, Verburg KM, Geis GS: Reduced incidence of gastroduodenal ulcers with celecoxib, a novel cyclooxygenase- 2 inhibitor, compared to naproxen in patients with arthritis. Am J Gastroenterol 2001;96: 1019-1027.

-46 Hawkey CJ, Svoboda P, Fiedorowicz-Fabrycy IF, Nasonov EL, Pikhlak EG, Cousin M, Gitton X, Hoexter G: Gastroduodenal safety and tolerability of lumiracoxib compared with ibuprofen and celecoxib in patients with osteoarthritis. J Rheumatol 2004;31: 1804-1810.

47 Kivitz AJ, Nayiager S, Schimansky T, Gimona A, Thurston HJ, Hawkey C: Reduced incidence of gastroduodenal ulcers associated with lumiracoxib compared with ibuprofen in patients with rheumatoid arthritis. Aliment Pharmacol Ther 2004;19:1189-1198.
48 Rostom A, Muir K, Dubé C, Jolicoeur E, Boucher M, Joyce J, Tugwell P, Wells GW: Gastrointestinal safety of cyclooxygenase-2 inhibitors: a Cochrane Collaboration systematic review. Clin Gastroenterol Hepatol 2007;5:818-828.

49 Hawkey CJ, Karrasch JA, Szczepañski L, Walker DG, Barkun A, Swannell AJ, Yeomans ND: Omeprazole compared with misoprostol for ulcers associated with nonsteroidal antiinflammatory drugs. Omeprazole versus Misoprostol for NSAID-induced Ulcer Management (OMNIUM) Study Group. N Engl J Med 1998;338:727-734.

50 Graham DY, Agrawal NM, Campbell DR, Haber MM, Collis C, Lukasik NL, Huang B, NSAID-Associated Gastric Ulcer Prevention Study Group: Ulcer prevention in longterm users of nonsteroidal anti-inflammatory drugs: results of a double-blind, randomized, multicenter, active- and placebo-controlled study of misoprostol vs lansoprazole. Arch Intern Med 2002;162:169-175.

51 Yeomans ND, Tulassay Z, Juhász L, Rácz I, Howard JM, van Rensburg CJ, Swannell AJ, Hawkey CJ: A comparison of omeprazole with ranitidine for ulcers associated with nonsteroidal antiinflammatory drugs. Acid Suppression Trial: Ranitidine versus Omeprazole for NSAID-associated Ulcer Treatment (ASTRONAUT) Study Group. N Engl J Med 1998;338:719-726.

52 Hooper L, Brown TJ, Elliott R, Payne K, Roberts C, Symmons D: The effectiveness of five strategies for the prevention of gastrointestinal toxicity induced by non-steroidal antiinflammatory drugs: systematic review. BMJ 2004;329:948.

53 Silverstein FE, Faich G, Goldstein JL, Simon LS, Pincus T, Whelton A, Makuch R, Eisen G, Agrawal NM, Stenson WF, Burr AM, Zhao WW, Kent JD, Lefkowith JB, Verburg KM, Geis GS: Gastrointestinal toxicity with celecoxib vs nonsteroidal anti-inflammatory drugs for osteoarthritis and rheumatoid arthritis: the CLASS study: a randomized controlled trial. Celecoxib Long-term Arthritis Safety Study. JAMA 2000;284:1247-1255.

54 Singh G, Fort JG, Goldstein JL, Levy RA, Hanrahan PS, Bello AE, Andrade-Ortega L, Wallemark C, Agrawal NM, Eisen GM, Stenson WF, Triadafilopoulos G, SUCCESS-I Investigators: Celecoxib versus naproxen and diclofenac in osteoarthritis patients: SUCCESS-I Study. Am J Med 2006;119:255-266.

55 Layton D, Hughes K, Harris S, Shakir SA: Comparison of the incidence rates of selected gastrointestinal events reported for patients prescribed celecoxib and meloxicam in general practice in England using prescription-event monitoring (PEM) data. Rheumatology (Oxford) 2003;42:1332-1341.
56 Chan FK, Hung LC, Suen BY, Wu JC, Lee KC, Leung VK, Hui AJ, To KF, Leung WK, Wong VW, Chung SC, Sung JJ: Celecoxib versus diclofenac and omeprazole in reducing the risk of recurrent ulcer bleeding in patients with arthritis. N Engl J Med 2002;347:2104-2110.

57 Chan FK, Wong VW, Suen BY, Wu JC, Ching JY, Hung LC, Hui AJ, Leung VK, Lee VW, Lai LH, Wong GL, Chow DK, To KF, Leung WK, Chiu PW, Lee YT, Lau JY, Chan HL, Ng EK, Sung JJ: Combination of a cyclo-oxygenase-2 inhibitor and a proton-pump inhibitor for prevention of recurrent ulcer bleeding in patients at very high risk: a double-blind, randomised trial. Lancet 2007;369:1621-1626.

58 The Japanese Society of Gastroenterology: The Guidelines on Management of Peptic Ulcers in Japan (in Japanese). Tokyo, Nankodo, 2009, p 105.

59 Mukherjee D, Nissen SE, Topol EJ: Risk of cardiovascular events associated with selective COX-2 inhibitors. JAMA 2001;286:954959.

60 Bresalier RS, Sandler RS, Quan H, Bolognese JA, Oxenius B, Horgan K, Lines C, Riddell R, Morton D, Lanas A, Konstam MA, Baron JA, Adenomatous Polyp Prevention on Vioxx (APPROVe) Trial Investigators: Cardiovascular events associated with rofecoxib in a colorectal adenoma chemoprevention trial. N Engl J Med 2005;352:1092-1102.

-61 Solomon SD, McMurray JJ, Pfeffer MA, Wittes J, Fowler R, Finn P, Anderson WF, Zauber A, Hawk E, Bertagnolli M, Adenoma Prevention with Celecoxib (APC) Study Investigators: Cardiovascular risk associated with celecoxib in a clinical trial for colorectal adenoma prevention. N Engl J Med 2005;352: 1071-1080.

62 Arber N, Eagle CJ, Spicak J, Rácz I, Dite P, Hajer J, Zavoral M, Lechuga MJ, Gerletti P, Tang J, Rosenstein RB, Macdonald K, Bhadra P, Fowler R, Wittes J, Zauber AG, Solomon SD, Levin B, PreSAP Trial Investigators: Celecoxib for the prevention of colorectal adenomatous polyps. N Engl J Med 2006;355: 885-895.

-63 ADAPT Research Group: Cardiovascular and cerebrovascular events in the randomized, controlled Alzheimer's Disease AntiInflammatory Prevention Trial (ADAPT). PLoS Clin Trials 2006;1:e33.

64 Solomon DH, Glynn RJ, Rothman KJ, Schneeweiss S, Setoguchi S, Mogun H, Avorn J, Stürmer T: Subgroup analyses to determine cardiovascular risk associated with nonsteroidal antiinflammatory drugs and coxibs in specific patient groups. Arthritis Rheum 2008;59:1097-1104.

65 Haag MD, Bos MJ, Hofman A, Koudstaal PJ, Breteler MM, Stricker BH: Cyclooxygenase selectivity of nonsteroidal anti-inflammatory drugs and risk of stroke. Arch Intern Med 2008;168:1219-1224. 
66 Rahme E, Nedjar H: Risks and benefits of COX-2 inhibitors vs non-selective NSAIDs: does their cardiovascular risk exceed their gastrointestinal benefit? A retrospective cohort study. Rheumatology (Oxford) 2007;46: 435-438.

67 Motsko SP, Rascati KL, Busti AJ, Wilson JP, Barner JC, Lawson KA, Worchel J: Temporal relationship between use of NSAIDs, including selective COX-2 inhibitors, and cardiovascular risk. Drug Saf 2006;29:621-632.

68 Huang WF, Hsiao FY, Tsai YW, Wen YW, Shih YT: Cardiovascular events associated with long-term use of celecoxib, rofecoxib and meloxicam in Taiwan: an observational study. Drug Saf 2006;29:261-272.

69 Hudson M, Richard H, Pilote L: Differences in outcomes of patients with congestive heart failure prescribed celecoxib, rofecoxib, or non-steroidal anti-inflammatory drugs: population based study. BMJ 2005;330:1370.

70 Solomon DH, Avorn J, Stürmer T, Glynn RJ, Mogun H, Schneeweiss S: Cardiovascular outcomes in new users of coxibs and nonsteroidal antiinflammatory drugs: high-risk subgroups and time course of risk. Arthritis Rheum 2006;54:1378-1389.

-71 Mamdani M, Juurlink DN, Lee DS, Rochon PA, Kopp A, Naglie G, Austin PC, Laupacis A, Stukel TA: Cyclo-oxygenase-2 inhibitors versus non-selective non-steroidal anti-inflammatory drugs and congestive heart failure outcomes in elderly patients: a population-based cohort study. Lancet 2004;363: 1751-1756.

-72 Mamdani M, Rochon P, Juurlink DN, Anderson GM, Kopp A, Naglie G, Austin PC, Laupacis A: Effect of selective cyclooxygenase 2 inhibitors and naproxen on short-term risk of acute myocardial infarction in the elderly. Arch Intern Med 2003;163:481-486.

73 Ray WA, Stein CM, Hall K, Daugherty JR, Griffin MR: Non-steroidal anti-inflammatory drugs and risk of serious coronary heart disease: an observational cohort study. Lancet 2002;359:118-123.

74 Ray WA, Stein CM, Daugherty JR, Hall K, Arbogast PG, Griffin MR: COX-2 selective non-steroidal anti-inflammatory drugs and risk of serious coronary heart disease. Lancet 2002;360:1071-1073.

-75 Warner JJ, Weideman RA, Kelly KC, Brilakis ES, Banerjee S, Cunningham F, Harford WV, Kazi S, Little BB, Cryer B: The risk of acute myocardial infarction with etodolac is not increased compared to naproxen: a historical cohort analysis of a generic COX-2 selective inhibitor. J Cardiovasc Pharmacol Ther 2008;13:252-260.

76 Schneeweiss S, Solomon DH, Wang PS, Rassen J, Brookhart MA: Simultaneous assessment of short-term gastrointestinal benefits and cardiovascular risks of selective cyclooxygenase 2 inhibitors and nonselective nonsteroidal antiinflammatory drugs: an instrumental variable analysis. Arthritis Rheum 2006;54:3390-3398.
77 Varas-Lorenzo C, Castellsague J, Stang MR, Perez-Gutthann S, Aguado J, Rodriguez LA The use of selective cyclooxygenase- 2 inhibitors and the risk of acute myocardial infarction in Saskatchewan, Canada. Pharmacoepidemiol Drug Saf 2009;18:1016-1025.

78 Andersohn F, Schade R, Suissa S, Garbe E: Cyclooxygenase-2 selective nonsteroidal anti-inflammatory drugs and the risk of ischemic stroke: a nested case-control study. Stroke 2006;37:1725-1730.

79 Kimmel SE, Berlin JA, Reilly M, Jaskowiak J, Kishel L, Chittams J, Strom BL: Patients exposed to rofecoxib and celecoxib have different odds of nonfatal myocardial infarction. Ann Intern Med 2005;142:157-164.

80 Graham DJ, Campen D, Hui R, Spence M, Cheetham C, Levy G, Shoor S, Ray WA: Risk of acute myocardial infarction and sudden cardiac death in patients treated with cyclooxygenase 2 selective and non-selective nonsteroidal anti-inflammatory drugs: nested case-control study. Lancet 2005;365:475481.

81 Hippisley-Cox J, Coupland C: Risk of myocardial infarction in patients taking cyclooxygenase- 2 inhibitors or conventional non-steroidal anti-inflammatory drugs: population based nested case-control analysis. BMJ 2005;330:1366.

82 Fischer LM, Schlienger RG, Matter CM, Jick H, Meier CR: Current use of nonsteroidal antiinflammatory drugs and the risk of acute myocardial infarction. Pharmacotherapy 2005;25:503-510.

83 Solomon DH, Schneeweiss S, Glynn RJ, Kiyota Y, Levin R, Mogun H, Avorn J: Relationship between selective cyclooxygenase- 2 inhibitors and acute myocardial infarction in older adults. Circulation 2004;109:20682073.

84 García Rodríguez LA, Varas-Lorenzo C, Maguire A, González-Pérez A: Nonsteroidal antiinflammatory drugs and the risk of myocardial infarction in the general population. Circulation 2004;109:3000-3006.

85 Bak S, Andersen M, Tsiropoulos I, García Rodríguez LA, Hallas J, Christensen K, Gaist D: Risk of stroke associated with nonsteroidal anti-inflammatory drugs: a nested casecontrol study. Stroke 2003;34:379-386.

86 Schlienger RG, Jick H, Meier CR: Use of nonsteroidal anti-inflammatory drugs and the risk of first-time acute myocardial infarction. Br J Clin Pharmacol 2002;54:327-332.

87 Watson DJ, Rhodes T, Cai B, Guess HA: Lower risk of thromboembolic cardiovascular events with naproxen among patients with rheumatoid arthritis. Arch Intern Med 2002 162:1105-1110.
88 Huerta C, Varas-Lorenzo C, Castellsague J, García Rodríguez LA: Non-steroidal antiinflammatory drugs and risk of first hospital admission for heart failure in the general population. Heart 2006;92:1610-1615.

-89 García Rodríguez LA, González-Pérez A: Long-term use of non-steroidal anti-inflammatory drugs and the risk of myocardial infarction in the general population. BMC Med 2005;3:17

-90 Johnsen SP, Larsson H, Tarone RE, McLaughlin JK, Nørgård B, Friis S, Sørensen HT: Risk of hospitalization for myocardial infarction among users of rofecoxib, celecoxib, and other NSAIDs: a population-based case-control study. Arch Intern Med 2005;165:978-984.

91 Brophy JM, Lévesque LE, Zhang B: The coronary risk of cyclo-oxygenase- 2 inhibitors in patients with a previous myocardial infarction. Heart 2007;93:189-194.

92 OECD (eds): Health at a Glance 2007: OECD Indicators. OECD Publishing, Paris 2007, p 26.

93 Whelton A, Lefkowith JL, West CR, Verburg KM: Cardiorenal effects of celecoxib as compared with the nonsteroidal anti-inflammatory drugs diclofenac and ibuprofen. Kidney Int 2006;70:1495-1502.

$\checkmark 94$ American College of Rheumatology Subcommittee on Rheumatoid Arthritis Guidelines: Guidelines for the management of rheumatoid arthritis: 2002 Update. Arthritis Rheum 2002;46:328-346.

95 Ochi T, Yamamoto K, Taki J (eds): Diagnostic Manual and EBM-Based Treatment Guidelines (in Japanese). Tokyo, Japan Rheumatism Foundation, 2004.

96 Zhang W, MoskowitzRW,NukiG, Abramson S, Altman RD, Arden N, Bierma-Zeinstra S, Brandt KD, Croft P, Doherty M, Dougados M, Hochberg M, Hunter DJ, Kwoh K, Lohmander LS, Tugwell P: OARSI recommendations for the management of hip and knee osteoarthritis. I. Critical appraisal of existing treatment guidelines and systematic review of current research evidence. Osteoarthritis Cartilage 2007;15:981-1000.

97 Zhang W, MoskowitzRW,Nuki G, Abramson S, Altman RD, Arden N, Bierma-Zeinstra S, Brandt KD, Croft P, Doherty M, Dougados M, Hochberg M, Hunter DJ, Kwoh K, Lohmander LS, Tugwell P: OARSI recommendations for the management of hip and knee osteoarthritis. II. OARSI evidence-based, expert consensus guidelines. Osteoarthritis Cartilage 2008;16:137-162.

98 Felson DT, Anderson JJ, Boers M, Bombardier C, Furst D, Goldsmith C, Katz LM, Lightfoot R Jr, Paulus H, Strand V, Tugwell P, Weinblatt M, Williams HJ, Wolfe F, Kieszak S: American College of Rheumatology. Preliminary definition of improvement in rheumatoid arthritis. Arthritis Rheum 1995;38: 727-735. 